\section{Amending Sandy Soil with Biochar Promotes Plant Growth and Root Colonization by Mycorrhizal Fungi in Highbush Blueberry}

\author{
Bryan K. Sales \\ Department of Horticulture, Agricultural and Life Sciences Building 4017, \\ Oregon State University, Corvallis, OR 97331 \\ David R. Bryla \\ U.S. Department of Agriculture, Agricultural Research Service, Horticultural \\ Crops Research Unit, 3420 NW Orchard Avenue, Corvallis, OR 97330
}

Kristin M. Trippe

U.S. Department of Agriculture, Agricultural Research Service, Forage Seed and Cereals Research Unit, 3450 SW Campus Way, Corvallis, OR 97331

Jerry E. Weiland and Carolyn F. Scagel

U.S. Department of Agriculture, Agricultural Research Service, Horticultural Crops Research Unit, 3420 NW Orchard Avenue, Corvallis, OR 97330

Bernadine C. Strik

Department of Horticulture, Agricultural and Life Sciences Building 4017, Oregon State University, Corvallis, OR 97331

\section{Dan M. Sullivan}

Department of Crop and Soil Science, Agricultural and Life Sciences Building 3017, Oregon State University, Corvallis, OR 97331

Additional index words. bokashi, ericoid mycorrhizal fungi, Phytophthora cinnamomi, soil amendments, Vaccinium corymbosum

\begin{abstract}
Biochar, a carbon-rich, fine-grained residue obtained from pyrolysis of biomass, is known to improve soil conditions and to suppress infection by soilborne pathogens. However, its use as a soil amendment has received relatively little attention by the horticulture industry. Two 12-week experiments were conducted in a greenhouse to determine the potential of using biochar, produced from mixed conifers during conversion of wood to energy, as a soil amendment for highbush blueberry (Vaccinium hybrid 'Legacy'). Plants in the first experiment were fertilized once a week with a complete fertilizer solution, whereas those the in the second experiment were fertilized once a month with a solution of ammonium sulfate. In both cases, the plants received the same amount of $\mathrm{N}$ in total and were grown in pots filled with unamended soil (sandy loam) or soil amended at rates of $10 \%$ or $20 \%$, by volume, with biochar or a 4:1 mix of biochar and bokashi (biochar-bokashi). The bokashi was produced from fermented rice (Oryza sativa L.) bran and was added to increase nutrients in the amendment. Half of the plants in each soil treatment were inoculated with Phytophthora cinnamomi Rands, which causes root rot in blueberry. Although pH of the raw biochar was high (8.5), soil pH averaged 4.5 to 5.5 in each treatment. In the absence of $P$. cinnamomi, plants grown with $20 \%$ biochar or $10 \%$ or $20 \%$ biochar-bokashi had greater leaf area and $30 \%$ to $70 \%$ more total dry weight than those grown with $10 \%$ biochar or in unamended soil. Biochar also improved soil aggregation and increased root colonization by ericoid mycorrhizal fungi. The percentage of roots colonized by mycorrhizal fungi was $54 \%$ to $94 \%$ in plants grown with the amendments, but was $\leq \mathbf{1 0 \%}$ in those grown in unamended soil. Plants inoculated with $P$. cinnamomi were stunted and showed typical symptoms of root rot. Root infection by the pathogen was unaffected by biochar or biochar-bokashi and negated any growth benefits of the amendments. Overall, amending soil with biochar appears to be a promising means of promoting plant growth and mycorrhizal colonization in blueberry, but it may not suppress phytophthora root rot.
\end{abstract}

Blueberry (Vaccinium sp.), a member of the Ericaceae family, is adapted to welldrained acidic soils with a high amount of organic matter (Retamales and Hancock,

2018). When blueberry is grown in mineral soils, organic materials such as bark or sawdust are often incorporated into the soil before planting to increase organic matter and improve soil structure (Bollen and Glennie, 1961; Haynes and Swift 1986); however, these materials are expensive (Julian et al., 2011). As a result, growers are interested in alternative strategies to improve soil conditions for better growth and production in blueberry.

Recently, there has been renewed interest in using biochar as a soil amendment for production in numerous crops (Suthar et al., 2018). Biochar is a highly stable, carbon-rich residue produced by pyrolysis, a process by which biomass is thermally decomposed under low oxygen conditions and typically at temperatures $<700{ }^{\circ} \mathrm{C}$ (Lehmann and Joseph, 2009). Essentially, any form of biomass can be converted to biochar, but the most preferable forms in terms of logistics and costs include forest thinnings, crop residues (e.g., corn stover, straw, grain husks), yard waste, clean urban wood waste (e.g., roadside clearing, pallets, sorted construction debris), and manures (Wang et al., 2015). Once applied, a large fraction of the biochar is recalcitrant and can persist in soil for decades to millennia (Lehmann and Joseph, 2009). Most biochars have high ion-exchange capacities (cation and anion) and, when added to soil, improve porosity and aeration and increase retention of water and nutrients (Bruun et al., 2014; Knowles et al., 2011; Nemati et al., 2015; Sohi et al., 2010).

Plant growth and productivity have been shown to respond positively to biochar addition, especially in acidic and coarse-textured soils (Jeffery et al., 2011). However, most biochars are high in $\mathrm{pH}(>7)$, which could be detrimental to acidophilic plants, such as blueberry. Biochar has also been reported to increase populations of beneficial soil microorganisms, such as mycorrhizal fungi (Amendola et al., 2017; Bird et al., 2008; LeCroy et al., 2013; Lehmann et al., 2011; Solaiman et al., 2010), and suppress development of soilborne pathogens, including $P$. cinnamomi (Zwart and Kim, 2012), which is commonly associated with root rot in highbush blueberry (Bryla et al., 2008; Yeo et al., 2016).

Recent studies suggest that biochar should be combined with other sources of organic matter to increase soil fertility even when biochar is applied at a lower rate. For example, mixing biochar with compost has been shown to increase plant productivity more than the combination of biochar and mineral fertilizers (Kammann et al., 2015; SánchezGarcía et al., 2016; Schulz and Glaser, 2012). Hagemann et al. (2017) determined that mixing the two results in a complex, nutrient-rich organic coating on the outer and inner surfaces of the biochar particles. This coating adds hydrophilicity, redoxactive moieties, and additional mesoporosity, which strengthens biochar-water interactions and enhances nutrient retention. However, compost is often high in $\mathrm{pH}$ and electrical conductivity and, therefore, can be unsuitable for blueberry (Costello et al., 2019; Strik et al., 2017; Sullivan et al., 2014).

Much like composting, bokashi is a process of converting food waste and other types 
of organic matter into a soil amendment. However, unlike compost, bokashi is produced by fermentation and is usually very low in $\mathrm{pH}$ (Christel, 2017). The process of making bokashi uses an inoculum of microorganisms called Effective Microorganisms or EM (Boechat et al., 2013). Typically, the inoculum contains a mix of microbes, such as Lactobacillus sp. (anaerobic bacteria), Rhodopseudomonas sp. (phototropic bacteria), Saccharomycetes sp. (yeast), actinomycetes, and various forms of filamentous fungi $(\mathrm{Xu}, 2000)$. Some of these microorganisms are considered antagonistic and capable of inducing systemic resistance in plants to various pathogens, including 'Candidatus phytoplasma solani' on periwinkle [Catharanthus roseus (L.) G. Don], bacterial blight (Erwinia psidii R.) on guava (Psidium guajava L.) fruits, Pythium ultimum Trow in cucumber ( $\mathrm{Cucu}$ mis sativus L.), and Rhizoctonia solani Kühn in carrot (Daucus carota L.) (Pierce et al., 2016; Rezende et al., 2008; Shin et al., 2017). The pores in biochar provide habitat for these microorganisms, protecting them from predation and drying (Lehmann et al., 2011). The high ion-exchange capacities of biochar can also help retain nutrients released from bokashi and other sources of organic matter (Dias et al., 2010; Prost et al., 2013).

The objective of this study was to evaluate the use of biochar alone or in combination with bokashi as a soil amendment for highbush blueberry. Two experiments were conducted, including one in which the plants in each treatment were fertigated once a week with a complete nutrient solution and another where the plants were fertigated once a month with a solution of ammonium sulfate only. Based on work in other crops, we expected that adding biochar to the soil would improve plant growth and mineral nutrition in blueberry and would be most effective under nutrient-limited conditions, such as those in the second study,

Received for publication 6 Sept. 2019. Accepted for publication 16 Dec. 2019.

Published online 6 February 2020.

Funds for this research were provided by the Northwest Center for Small Fruits Research, Family Forests of Oregon, and the U.S. Department of Agriculture (CRIS number 2072-21000-048-00D). We thank Matt Delaney for help with experimental planning, Paul Schreiner for assistance with identifying mycorrhizal structures in the roots, Scott Orr and Suean Ott for technical assistance, and John Miedema for providing the soil amendments. Mention of trade names or commercial products in this publication is solely for the purpose of providing specific information and does not imply recommendation or endorsement by the U.S. Department of Agriculture.

Current address for B.K.S.: University of North Carolina at Pembroke, 2233 Oxendine Science Building, 1 University Drive, Pembroke, NC 28372.

B.K.S. is a former Ph.D. student.

D.R.B. is the corresponding author. E-mail: david. bryla@usda.gov.

This is an open access article distributed under the CC BY-NC-ND license (https://creativecommons. org/licenses/by-nc-nd/4.0/). when it was mixed with bokashi. We also inoculated half of the plants in each treatment with $P$. cinnamomi to determine whether biochar or biochar and bokashi enhanced disease suppression of the pathogen.

\section{Materials and Methods}

Soil amendments. The soil amendments used in the study included biochar and a 4:1 mix of biochar and bokashi (v/v). The biochar was produced by gasification at $\approx 750{ }^{\circ} \mathrm{C}$ (Oregon Biochar Solutions, Central Point, OR). This is a commercially available biochar manufactured from mixed conifers during conversion of wood to energy at Biomass One, a 30-MW wood-debris-fired power plant (White City, OR). The bokashi was produced from rice bran fermented with EM1 microbial inoculant (TeraGanix, Inc., Alto, TX). Physicochemical properties of the biochar were obtained from laboratory tests provided by the manufacturer or conducted in the laboratory of KMT (Table 1).

Phytophthora inoculum. Inoculum of $P$. cinnamomi was produced in fungal spawn bags with filter patches (Fungi Perfecti, Sheldon, WA). Twenty-seven bags were filled with $3 \mathrm{~L}$ of medium-grade vermiculite and $1.5 \mathrm{~L}$ of a broth with $7.5 \%$ vegetable juice (V-8 juice; Campbell Soup Co., Camden, $\mathrm{NJ}$ ), by volume, and $1 \mathrm{~g} \cdot \mathrm{L}^{-1} \mathrm{CaCO}_{3}$. The bags were autoclaved three times for $55 \mathrm{~min}$ every $24 \mathrm{~h}$. After cooling, a 100-mmdiameter petri plate of potato dextrose agar (Difco Laboratories Inc., Detroit, MI), fully colonized with a 10-d-old isolate of $P$. cinnamomi, was sliced into 100 pieces and added to each bag (i.e., one plate/bag). The isolate was obtained in 2010 from an infected, field-grown plant of 'Draper' blueberry (Vargas et al., 2015) and was used previously by Yeo et al. (2016). Bags of vermiculite were also mixed with agar plugs without the pathogen and used for the noninoculated controls. Each bag was incubated in the dark at $20^{\circ} \mathrm{C}$ and shaken at 1-week intervals. After 4 weeks, the contents of each bag were consolidated and homogenized in a cement mixer and weighed. The inoculated vermiculite was separated into five different bags, each containing $416 \mathrm{~g}$ fresh weight of inoculated vermiculite. The density of propagules in the vermiculite was enumerated by plating a suspension of $10 \mathrm{~mL}$ of inoculum in $90 \mathrm{~mL}$ of $0.2 \%$ water agar onto 10 plates of potato dextrose agar, incubating for $48 \mathrm{~h}$ in the dark, and then counting the number of $P$. cinnamomi colonies.

Soil treatments. The soil used in the experiments was a Lynden sandy loam (sandy, mixed, mesic Typic Haplorthods) collected from the top $30 \mathrm{~cm}$ of an area adjacent to a commercial blueberry field in Whatcom County, WA. The soil was airdried, sieved through a 2-mm-mesh screen, and combined in a cement mixer with $10 \%$ or $20 \%$ biochar or biochar-bokashi, by volume. During mixing, a bag of inoculated $(P$. cinnamomi) or noninoculated (control) vermiculite was also added with each amendment, as well as to treatments with soil only. In total, there were 10 different soil treatments, including a combination of five levels of soil amendment (none, 10\% biochar, 20\% biochar, $10 \%$ biochar-bokashi, and $20 \%$ biochar-bokashi) and two levels of inoculation with $P$. cinnamomi (noninoculated and inoculated). The noninoculated treatments were mixed first, and the mixer was sanitized with $0.5 \% \mathrm{NaOCl}$ solution between each treatment. Final density of the pathogen in the inoculated treatments was 2.7 colonyforming units (cfu) per $\mathrm{cm}^{3}$ of soil or soil mix.

Experimental design. Experiments were initiated on 4 Apr. 2016 in a heated glasshouse located at the U.S. Department of Agriculture-Agricultural Research Service Horticultural Crops Research Unit in Corvallis, OR (lat. $44^{\circ} 34^{\prime} 3^{\prime \prime} \mathrm{N}$, long. $123^{\circ} 17^{\prime} 9^{\prime \prime} \mathrm{W}$ ). One hundred 'Legacy' blueberry plants were obtained from a commercial nursery (Fall Creek Farm \& Nursery, Lowell, OR) as 1year-old liners propagated from tissue culture. The plants were transplanted into 4-L plastic pots (one plant per container) filled

Table 1. Physicochemical properties of the biochar used in the study.

\begin{tabular}{lcl}
\hline Property & Value & Test method \\
\hline Surface area $\left(\mathrm{m}^{2} \cdot \mathrm{g}^{-1}\right)$ & 554 & ASTM D6556-10 \\
Bulk density $\left(\mathrm{kg} \cdot \mathrm{m}^{-3}\right)$ & 78.5 & ASTM D6556-10 \\
Total ash $(\%)$ & 2.7 & ASTM D1762-84 \\
Volatile matter $(\%)$ & 9.3 & ASTM D1762-84 \\
Fixed C $(\%)$ & 88 & Dry combustion \\
$\mathrm{H}: \mathrm{C}$ ratio & 0.25 & Dry combustion \\
$\mathrm{N}(\%)$ & 0.94 & Dry combustion \\
Electrical conductivity $\left(\mathrm{dS} \cdot \mathrm{m}^{-1}\right)$ & 1.21 & 4.10USCC:dil. Rajkovich \\
Liming equivalent $(\% \mathrm{CaCO} 3)$ & 11.1 & AOAC 955.01 \\
Carbonates $\left(\% C a C \mathrm{CO}_{3}\right)$ & 5.1 & ASTM D 4373 \\
Tetra dioxins $\left(\mathrm{ng} \cdot \mathrm{kg}^{-1}\right)$ & 4.09 & US EPA 8290 \\
Tetra furans $\left(\mathrm{ng} \cdot \mathrm{kg}^{-1}\right)$ & 31.4 & US EPA 8290 \\
Penta furans $\left(\mathrm{ng} \cdot \mathrm{kg}^{-1}\right)$ & 4.27 & US EPA 8290 \\
Particle size class $(\%)$ & & ASTM D 2862 granular \\
$<0.5 \mathrm{~mm}$ & 1.4 & \\
$0.5-1 \mathrm{~mm}$ & 3.2 & \\
$1-2 \mathrm{~mm}$ & 49.8 & \\
$2-4 \mathrm{~mm}$ & 43.9 & \\
$>4$ mm & 1.8 & \\
\hline
\end{tabular}

${ }^{\mathrm{z}}$ See International Biochar Initiative (2015) for a full description of each method. 
with each soil treatment (10 plants/treatment) and divided into two experiments, referred to as Expt. 1 and Expt. 2. In Expt. 1, six plants per treatment were fertigated weekly with $100 \mathrm{~mL}$ of a complete nutrient solution (Miracle-Gro Water Soluble Azalea, Camellia, Rhododendron Plant Food; The Scotts Company, Marysville, OH). The solution had $150 \mathrm{mg} \cdot \mathrm{L}^{-1}$ of $\mathrm{N}$ and $50 \mathrm{mg} \cdot \mathrm{L}^{-1}$ each of $\mathrm{P}$ and K. In Expt. 2, four plants per treatment were fertigated once every 4 weeks with $100 \mathrm{~mL}$ of ammonium sulfate solution containing 600 $\mathrm{mg} \cdot \mathrm{L}^{-1}$ of $\mathrm{N}$. The plants were also irrigated two or three times per week, as needed, in both of the experiment, with sufficient water to produce $\approx 20 \%$ drainage from the pots during each irrigation. Overall, the plants received the same total amount of $\mathrm{N}$ in both experiments, but in Expt. 2, $\mathrm{N}$ was applied less frequently, and no additional nutrients other than $\mathrm{S}$ were added.

The experiments were arranged in a completely randomized design and conducted side-by-side on the same greenhouse bench. Each pot was mulched with a 2.5 -cm-layer of douglas fir [Pseudotsuga menziesii (Mirb.) Franco] sawdust to reduce soil evaporation and to prevent the growth of moss and algae on the soil surface. Temperature inside the glasshouse was maintained at $28 \pm 2{ }^{\circ} \mathrm{C}$ during the day and $20 \pm 2{ }^{\circ} \mathrm{C}$ at night. Photoperiod was extended to $14 \mathrm{~h} \cdot \mathrm{d}^{-1}$ using two $1000-\mathrm{W}$ high-pressure sodium lamps suspended $\approx 1.5 \mathrm{~m}$ above the pots.

To promote infection by $P$. cinnamomi, plants from both experiments were flooded for $48 \mathrm{~h}$ at 6 and 8 weeks after transplanting (Weiland et al., 2010). During flooding, each pot was placed inside a 3.8-L plastic bucket filled with $3.2 \mathrm{~L}$ of tap water to $\approx 1.5 \mathrm{~cm}$ below the surface of the soil. Care was taken to avoid splashing during the procedure, and all buckets were sanitized with $0.5 \% \mathrm{NaOCl}$ solution before each flooding event (Weiland et al., 2018).

Measurements. A 4-L sample of the soil and the amendments (biochar and biocharbokashi) was sent to a commercial laboratory (Brookside Laboratories, New Bremen, $\mathrm{OH}$ ) for initial (preexperiment) analysis of $\mathrm{pH}$, organic matter, nutrients, and texture (soil only). The $\mathrm{pH}$ of each was determined using a 1:1 ratio with water (McLean, 1982), and organic matter content was determined by loss-on-ignition at $360{ }^{\circ} \mathrm{C}$ (Shulte and Hopkins, 1996). Available $\mathrm{N}\left(\mathrm{NH}_{4}-\mathrm{N}\right.$ and $\left.\mathrm{NO}_{3}-\mathrm{N}\right)$ was extracted with $1 \mathrm{M} \mathrm{KCl}$ and determined using automated colorimetric methods (Dahnke and Johnson, 1990). Other nutrients were extracted using the Mehlich 3 (Mehlich, 1984) method and analyzed by inductively coupled plasma (ICP) spectrometry. Soil texture was determined using the hydrometer method (ASTM D422-63, 2007).

Leaf area was estimated weekly during the experiments by measuring the length and width of every leaf on the plants using a standard 30-cm-length ruler. Each measurement was converted to leaf area using linear model developed for highbush blueberry (Follovo et al., 2008).
Plants from both experiments were harvested destructively at 12 weeks after transplanting. At harvest, a 100-g sample of soil was collected first from each pot (noninoculated treatments only) and sent to the commercial laboratory mentioned previously for analysis of $\mathrm{pH}$, organic matter, and nutrients. Next, the leaves were removed from the plants and measured using a portable leaf area meter (LI-3000C; LICOR Biosciences, Logan, UT). Then, the stems were cut off at the soil surface, and soil was washed from the roots by rinsing them under running water. Two random samples of roots (1-2 $g$ fresh weight each) were taken from each plant and placed in $50-\mathrm{mL}$ tubes for analysis of colonization by ericoid mycorrhizal fungi and infection by $P$. cinnamomi. The leaves, stems, and remaining roots were oven-dried for $2 \mathrm{~d}$ at $60{ }^{\circ} \mathrm{C}$ and weighed.

Once weighed, the leaves were ground to pass through a 20 -mesh screen and analyzed for $\mathrm{N}$ using a combustion analyzer (TruSpec $\mathrm{CN}$; Leco Corp., St. Joseph, MI) and for other nutrients $(\mathrm{P}, \mathrm{K}, \mathrm{Ca}, \mathrm{Mg}, \mathrm{S}, \mathrm{B}, \mathrm{Cu}, \mathrm{Fe}$, $\mathrm{Mn}$, and $\mathrm{Zn}$ ) using an ICP optical emission spectrophotometer (Optima 3000DV; Perkin Elmer, Wellesley, MA). Samples were digested in a microwave with $70 \%(\mathrm{v} / \mathrm{v})$ nitric acid before running them on the ICP (Gavlak et al., 2005). Reference standard apple [Malus Xsylvestris (L.) Mill. var. domestica (Borkh.) Mansf.] leaves (no. 151, National Institute of Standards and Technology) were included in each run to ensure the accuracy of the instruments and digestion procedures.

Roots collected for mycorrhizal analysis were cleared with $10 \% \mathrm{KOH}$ and stained in a solution of lactoglyceride and $0.05 \%$ trypan blue (Giovannetti and Mosse, 1980). Roots were also collected from 10 plants before planting to determine the level of initial colonization. Each root sample was examined under a microscope $(\times 115)$ and quantified for percent colonization using the gridline-intersection method (McGonigle et al., 1990). Approximately $1 \mathrm{~g}$ of stained roots were placed onto a petri dish and spread out evenly. The dish was marked on the bottom with horizontal and vertical gridlines. Each time a root intersected a gridline, the presence or absence of mycorrhizal structures (hyphae and hyphal coils) was recorded. Because Phytophthora also produces hyphae, mycorrhizal colonization was not examined in plants inoculated with $P$. cinnamomi.

Roots collected for analysis of Phytophthora were rinsed in $1 \%$ bleach solution $(0.05 \% \mathrm{NaOCl})$ for $30 \mathrm{~s}$, and ten $1-\mathrm{cm}$-long pieces from each sample were placed onto petri plates filled with $\mathrm{P}_{10} \mathrm{ARPH}$ agar, a semiselective medium for Phytophthora $\mathrm{sp}$ (Tsao and Guy, 1977). The agar contained 10 ppm pimaricin (Sigma-Aldrich, St. Louis, MO), $250 \mathrm{ppm}$ ampicillin (Sigma-Aldrich), $10 \mathrm{ppm}$ rifampicin (Sigma-Aldrich), 100 ppm pentachloronitrobenzene (Terrachlor, $75 \%$ a.i.; Chemtura, Middlebury, CT), and 25 ppm hymexazol (Tachigaren, 70\% a.i.; Sankyo Co., Tokyo, Japan). The plates were incubated at $20{ }^{\circ} \mathrm{C}$ for $10 \mathrm{~d}$ and monitored periodically under a microscope $(\times 400)$ to determine the percentage of the root sections infected by $P$. cinnamomi.

Statistical analyses. Data were analyzed separately from the two experiments. In both cases, the data were tested for normality (Shapiro-Wilk) and homogeneity of variance (Brown-Forsythe) and analyzed by analysis of variance using a statistical software package (Systat Software Inc., San Jose, CA). Fixed effects in the model included amendment type and inoculation treatment. For analysis of repeated leaf area measurements, fixed effects included amendment, inoculation, and week. To homogenize variance, root infection and mycorrhizal root colonization were transformed using the arcsinesquare root transformation. After statistical analysis, data were back transformed to represent the actual means. In some instances, variance could not be homogenized successfully by transformation, and the data were reanalyzed using the Kruskal-Wallis test by ranks (soil $\mathrm{pH}, \mathrm{Mg}$, and $\mathrm{Mg}$ in Expt. 1 and soil $\mathrm{SO}_{4}-\mathrm{S}$ in Expt. 2). When effects were significant, means were separated at the $5 \%$ level using Tukey's honestly significant difference test.

Table 2. Initial chemical and physical characteristics of soil and amendments (biochar and 4 biochar: 1 bokashi) used in the study.

\begin{tabular}{lccc}
\hline Characteristic & Soil & Biochar & Biochar-bokashi \\
\hline pH & 5.7 & 8.5 & 8.8 \\
Organic matter $(\%)$ & 1.6 & 20.5 & 31.3 \\
$\mathrm{NH}_{4}-\mathrm{N}\left(\mathrm{mg}^{-1} \mathrm{~kg}^{-1}\right)$ & 1 & $<0.5$ & 24 \\
$\mathrm{NO}_{3}-\mathrm{N}\left(\mathrm{mg} \cdot \mathrm{kg}^{-1}\right)$ & 3 & 2 & 19 \\
$\mathrm{P}\left(\mathrm{mg} \cdot \mathrm{kg}^{-1}\right)$ & 88 & 60 & 673 \\
$\mathrm{SO}-\mathrm{S}\left(\mathrm{mg} \cdot \mathrm{kg}^{-1}\right)$ & 26 & 12 & 29 \\
$\mathrm{~K}(\mathrm{meq} / 100 \mathrm{~g})$ & 1.12 & 1.93 & 7.68 \\
$\mathrm{Ca}(\mathrm{meq} / 100 \mathrm{~g})$ & 1.85 & 1.52 & 1.97 \\
$\mathrm{Mg}(\mathrm{meq} / 100 \mathrm{~g})$ & 0.37 & 0.37 & 2.16 \\
$\mathrm{~B}\left(\mathrm{mg} \cdot \mathrm{kg}^{-1}\right)$ & 0.54 & 0.69 & 0.50 \\
$\mathrm{Cu}\left(\mathrm{mg} \cdot \mathrm{kg}^{-1}\right)$ & 2.4 & 0.8 & 1.1 \\
$\mathrm{Mn}\left(\mathrm{mg} \cdot \mathrm{kg}^{-1}\right)$ & 37 & 49 & 6.7 \\
$\mathrm{Zn}\left(\mathrm{mg} \cdot \mathrm{kg}^{-1}\right)$ & 2.0 & 2.1 & - \\
Sand $(\%)$ & 75.0 & - & - \\
Silt $(\%)$ & 14.7 & - & - \\
Clay $(\%)$ & 10.3 & &
\end{tabular}




\section{Results}

Physicochemical properties of the soil, biochar, and biochar-bokashi amendments

Initial characteristics of the soil and amendments before planting. The soil used in the study was sandy and acidic with low organic matter content (Table 2). Available soil $\mathrm{N}$ was also low, but other extractable nutrients, including $\mathrm{P}, \mathrm{K}, \mathrm{Ca}$, and $\mathrm{Mg}$, were sufficient for production of highbush blueberry (Hart et al., 2006; Horneck et al., 2011). Biochar and biocharbokashi, in contrast, were high in $\mathrm{pH}$ and organic matter, and the latter had much higher concentrations of $\mathrm{NH}_{4}-\mathrm{N}, \mathrm{NO}_{3}-\mathrm{N}, \mathrm{P}$, $\mathrm{K}, \mathrm{Mg}$, and $\mathrm{Zn}$ than the soil or biochar.

Characteristics of the soil after the final destructive harvest. After 12 weeks, soil $\mathrm{pH}$ averaged 4.6 and 5.3 in Expts. 1 and 2, respectively, and was slightly lower in unamended soil than in soil with $20 \%$ biochar or $10 \%$ or $20 \%$ biochar-bokashi in Expt. 2 (Table 3). These three amendments also increased soil organic matter in Expt. 1 and $\mathrm{NO}_{3}-\mathrm{N}$ and $\mathrm{K}$ in Expt. 2. Several other nutrients increased with biochar-bokashi in Expt. 2, including soil $\mathrm{P}$ and $\mathrm{Zn}$, which were both greater with $20 \%$ of the amendment than with any other treatment, and soil $\mathrm{Mg}$, which was greater with $10 \%$ or $20 \%$ of the amendment than in unamended soil.

The average concentration of most nutrients in the soil was similar between the two experiments (Table 3). However, soil $\mathrm{NO}_{3}-\mathrm{N}$ was much higher in Expt. 1 than in Expt. $2\left(\bar{X}=87\right.$ and $12 \mathrm{mg} \cdot \mathrm{kg}^{-1} \mathrm{NO}_{3}$ $\mathrm{N}$, respectively). Soil $\mathrm{K}$ was also higher in Expt. $1(\bar{X}=0.50$ and 0.33 meq K per $100 \mathrm{~g}$ soil, respectively), whereas soil $\mathrm{SO}_{4}-\mathrm{S}$ was higher in Expt. $2\left(\bar{X}=27\right.$ and $44 \mathrm{mg} \cdot \mathrm{kg}^{-1}$ $\mathrm{SO}_{4}-\mathrm{S}$, respectively).

Soil aggregates formed around many of the larger fragments ( $>1 \mathrm{~mm}$ in length) of biochar in the pots (Fig. 1). The aggregates consisted primarily of silt and clay particles and were absent in the unamended soil.

\section{Plant growth}

Leaf area development. Leaf area increased over time in both experiments and was significantly affected by an interaction between the soil amendments and inoculation with $P$. cinnamomi $(P<$ $0.001)$. In each case, leaf area was similar among the noninoculated treatments, until 10 to 11 weeks after transplanting, at which time leaf area was greater in plants grown with $20 \%$ biochar or $10 \%$ or $20 \%$ biochar-bokashi than in those grown with $10 \%$ biochar or no amendments (Fig. 2). In contrast, leaf area was unaffected by the soil amendments when the plants were inoculated with $P$. cinnamomi.

Plant dry weight. Shoot, root, and total dry weight of the plants were significantly affected by an interaction between the soil amendment treatments and inoculation with $P$. cinnamomi in Expts. 1 and 2

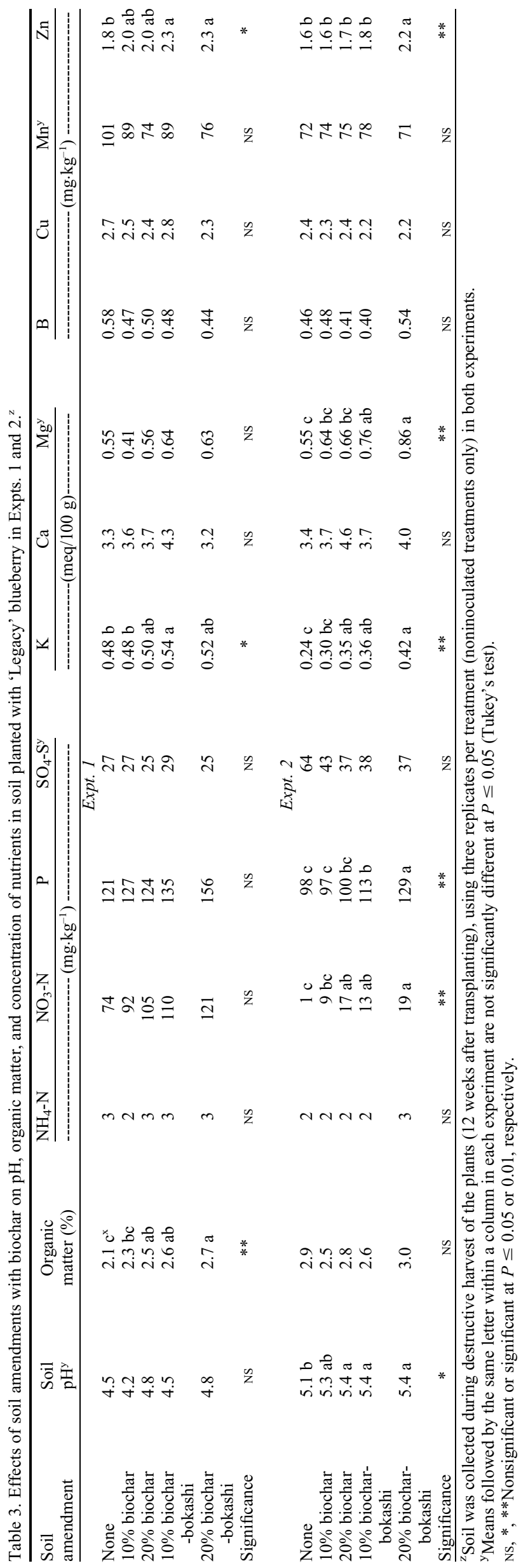


$(P<0.001)$. Without inoculum, plants in both experiments produced more total dry weight with $20 \%$ biochar or $10 \%$ or $20 \%$ biocharbokashi than with $10 \%$ biochar or no amendment and had the greatest dry weight with $20 \%$ biochar in Expt. 1 and with $20 \%$ biochar-bokashi in Expt. 2 (Fig. 3). In contrast, dry weight was similar between plants grown with amendments and those grown with no amendment when the soil was inoculated with $P$. cinnamomi. Inoculation resulted in a high

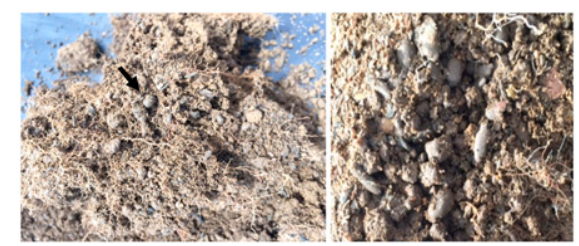

Fig. 1. Formation of aggregates (arrow) in soil amended with a woody biochar. A close-up of a large group of aggregates in soil with biochar is shown on the right. The soil was sandy and lacked structure without the biochar. percentage of red leaves on the plants and reduced total dry weight by an average of $38 \%$ in Expt. 1 and $71 \%$ in Expt. 2. None of the plants died during the experiments.

\section{Leaf nutrient analysis}

Macronutrients. The concentration of specific macronutrients in the leaves was affected by the soil amendments, as well as by inoculation by $P$. cinnamomi or interactions between the amendments and inoculation, in one or both of the experiments (Table 4). In many cases, the concentration of specific nutrients differed between plants grown in unamended soil and those grown in soil with biochar or biochar-bokashi. For example, regardless of inoculation, leaf $\mathrm{K}$, $\mathrm{Mg}$, and S were greater with $10 \%$ or $20 \%$ biochar-bokashi than with no amendment in Expt. 1, whereas leaf $\mathrm{N}$ and $\mathrm{S}$ were greater with most or all amendments than with no amendment in Expt. 2. Likewise, leaf P was greater with $20 \%$ biochar-bokashi, which contained a high amount of $\mathrm{P}$ (Table 2), than with any other treatment in Expt. 2.

\section{Expt. 1}

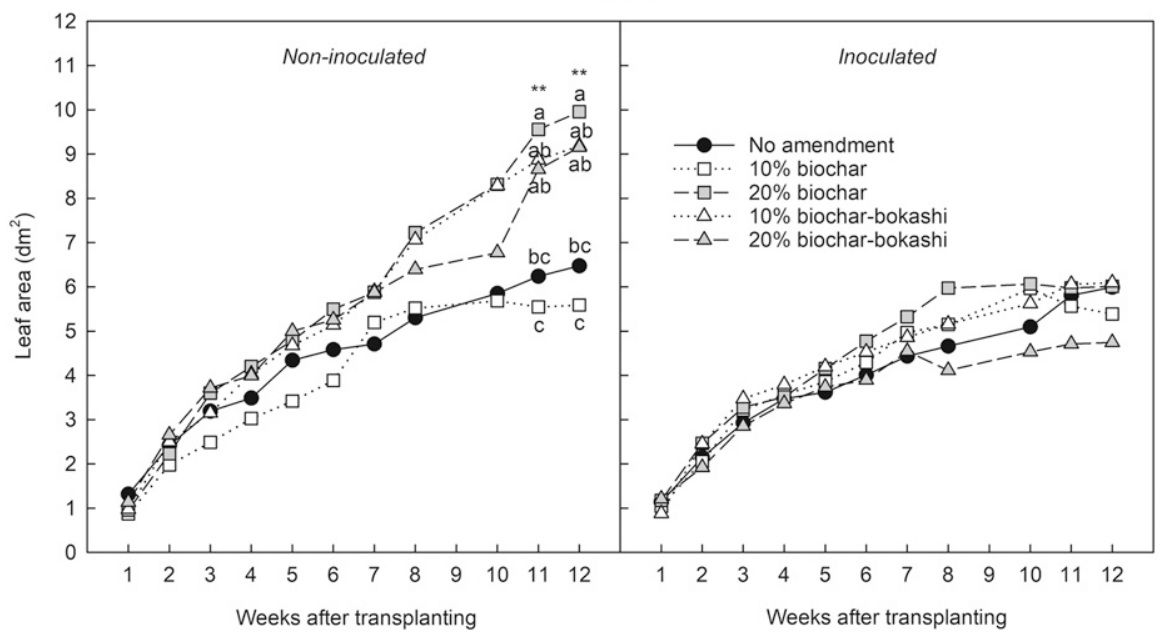

Expt. 2

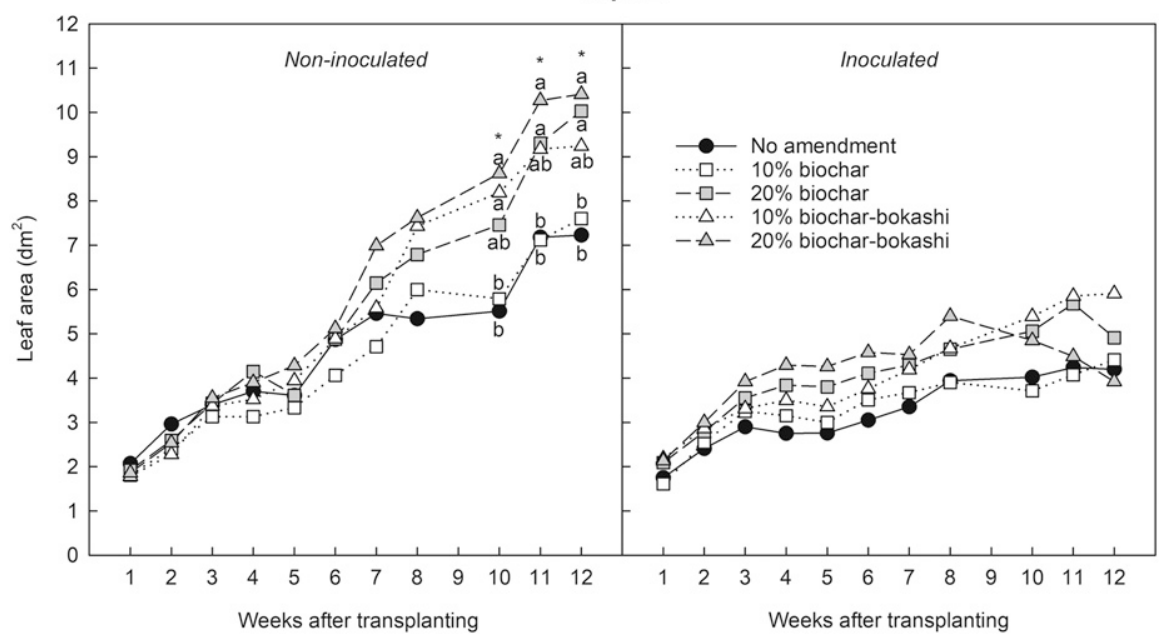

Fig. 2. Effects of a combination of soil amendments with biochar and inoculation with Phytophthora cinnamomi on leaf area development of 'Legacy' blueberry in Expts. 1 and 2. Asterisks indicate weeks in which leaf area differed significantly among the treatments at $P \leq 0.05\left(^{*}\right)$ or $0.01\left(^{* *}\right)$. Means followed by the same letter within a given week are not significantly different at $P \leq 0.05$ (Tukey's test).
Several leaf macronutrient concentrations were also greater, on average, when plants were grown in soil inoculated with $P$. cinnamomi than when they were not, including leaf $\mathrm{P}, \mathrm{K}$, and $\mathrm{S}$ in Expt. 1 and leaf $\mathrm{N}$ and $\mathrm{K}$ in Expt. 2 (Table 4). However, leaf $\mathrm{P}$ and, in some amendment treatments, $\mathrm{Mg}$ were lower with inoculation than with no inoculum in Expt. 2.

In general, the average concentration of $\mathrm{N}$, $\mathrm{P}, \mathrm{K}$, and $\mathrm{Ca}$ in the leaves was higher in Expt. 1 than in Expt. 2, whereas the concentration of $\mathrm{Mg}$ and $\mathrm{S}$ in the leaves was higher in Expt. 2 than in Expt. 1 (Table 4). As mentioned, plants in Expt. 1 were fertigated weekly with a complete nutrient solution, while those in Expt. 2 were fertigated once every 4 weeks with ammonium sulfate (i.e., $\mathrm{N}$ fertilizer only).

Micronutrients. The concentration of micronutrients in the leaves was also affected by the soil amendments, inoculation, or their interaction in Expts. 1 and 2 (Table 5). For specific micronutrients, concentrations differed between plants grown in unamended soil and those grown with biochar or biocharbokashi. For example, when the plants were noninoculated in Expt. 1, leaf B, Mn, and Zn decreased with $20 \%$ biochar or, in the case of B, $10 \%$ or $20 \%$ biochar-bokashi. Leaf B and Mn likewise decreased with 20\% biochar (regardless of inoculation) or $10 \%$ biocharbokashi (noninoculated plants only), respectively, in Expt. 2.

In many cases, inoculation with $P$. cinnamomi increased the concentration of $\mathrm{B}$ and $\mathrm{Mn}$ and reduced the concentration of $\mathrm{Cu}, \mathrm{Fe}$, and $\mathrm{Zn}$ in the leaves compared with no inoculum (Table 5). However, results varied, depending on the amendment. For example, in Expt. 1, inoculation resulted in higher concentrations of B and $\mathrm{Mn}$ when the plants were grown with $20 \%$ biochar-bokashi or $10 \%$ biochar, respectively, but had no effect when they were grown with the other amendments. Likewise, inoculation had no effect on leaf $\mathrm{Cu}$ or $\mathrm{Zn}$ when plants were grown with no amendment or with biochar-bokashi $(10 \%$ or $20 \%$ ), respectively, in Expt. 1, and led to a lower concentration of $\mathrm{Fe}$ in the leaves when plants were grown with $10 \%$ biocharbokashi, as well as no effect with several amendments on leaf Fe, Mn, or Zn, in Expt. 2.

\section{Root colonization by mycorrhizal fungi}

Root colonization by ericoid mycorrhizal fungi averaged $1.5 \%$ before planting (data not shown) and, after 12 weeks, increased to $\leq 9 \%$ when noninoculated plants were grown in unamended soil and $\geq 56 \%$ when they were grown in soil with biochar or biocharbokashi (Table 6). In both experiments, colonization was greater, on average, when a higher percentage of the amendments was added to the soil $(P<0.05)$ and when plants were grown with biochar-bokashi rather than biochar $(P<0.01)$.

\section{Root infection by $P$. cinnamomi}

Roots collected from the inoculated plants were heavily infected by $P$. cinnamomi (Table 7); however, infection was unaffected by the soil amendments in either experiment. 
None of the noninoculated plants were infected by the pathogen.

\section{Discussion}

In two experiments, biochar (alone or mixed with bokashi) increased plant growth relative to using unamended soil in highbush blueberry. However, increases in growth varied among treatments and were dependent on the amendment type, the level of fertilization, and the rate at which the amendment was incorporated. When plants were fertigated with a complete nutrient solution (Expt. 1), the highest biomass and leaf area were obtained in soil with $20 \%$ biochar. Previous studies indicate that biochar has the greatest influence on plant growth when it is applied in conjunction with fertilizers (Hossain et al., 2015; Meng et al., 2018; Schulz and Glaser, 2012; Zheng et al., 2015). Biochars derived from woody materials, such as conifers, generally have a high $\mathrm{C}: \mathrm{N}$ ratio and low concentrations of available nutrients; therefore, they are not expected to act directly as a fertilizer source (Singh et al., 2010). This might explain why biochar did better with bokashi when the plants were fertigated with fertilizer solution containing only a $\mathrm{N}$ source (i.e., Expt. 2)

Regardless of the rate in which the amendments were applied, biochar and biochar-bokashi had little to no effect on soil $\mathrm{pH}$ in the present study. In fact, by 12 weeks after transplanting, soil $\mathrm{pH}$ was lower in each treatment than it was before planting. Increases in soil $\mathrm{pH}$ associated with the use of biochar are well documented and often correlated to the rate at which the biochar was applied (Molnár et al., 2016; Xu et al., 2012; Zhao et al., 2015); however, decreases in soil $\mathrm{pH}$ following the application of biochar have also been documented (Cornelissen et al., 2018; Lehman and Joseph, 2009). The influence that biochar has on soil $\mathrm{pH}$ depends on the liming equivalency of the amendment and the buffering capacity of the soil (Yuan and $\mathrm{Xu}, 2011)$. In our experiments, the acidifying effect of the ammonium fertilizer was likely greater than the liming effect of the biochar (Havlin et al., 2005; Robertson and Groffman, 2015). Likewise, van Zwieten et al. (2010) reported similar findings while investigating the effect of increasing rates of biochar and urea on wheat (Triticum

Fig. 3. Effects of a combination of soil amendments with biochar and inoculation with Phytophthora cinnamomi on shoot and root dry weight of 'Legacy' blueberry in Expts. 1 and 2. Similar letters within each inoculation treatment indicate shoot and root dry weight (lower-case letters) and total dry weight (upper-case letters) are not significantly different at $P \leq 0.05$ (Tukey's test).

Table 4. Effects of a combination of soil amendments with biochar and inoculation with Phytophthora cinnamomi on the concentration of macronutrients in leaves of 'Legacy' blueberry in Expts. 1 and 2.

\begin{tabular}{|c|c|c|c|c|c|c|c|c|c|c|c|c|c|c|c|}
\hline \multirow[b]{2}{*}{ Soil amendment } & \multicolumn{2}{|c|}{$\mathrm{N}\left(\mathrm{mg} \cdot \mathrm{g}^{-1}\right)$} & \multicolumn{2}{|c|}{$\mathrm{P}\left(\mathrm{mg} \cdot \mathrm{g}^{-1}\right)$} & \multicolumn{3}{|c|}{$\mathrm{K}\left(\mathrm{mg} \cdot \mathrm{g}^{-1}\right)$} & \multicolumn{3}{|c|}{$\mathrm{Ca}\left(\mathrm{mg} \cdot \mathrm{g}^{-1}\right)$} & \multicolumn{3}{|c|}{$\mathrm{Mg}\left(\mathrm{mg} \cdot \mathrm{g}^{-1}\right)$} & \multicolumn{2}{|c|}{$\mathrm{S}\left(\mathrm{mg} \cdot \mathrm{g}^{-1}\right)$} \\
\hline & NI & I & NI & I & NI & I & $\overline{\text { Difference }}$ & $\mathrm{NI}$ & I & $\overline{\text { Difference }}$ & $\mathrm{NI}$ & I & $\overline{\text { Difference }}$ & NI & $\mathrm{I}$ \\
\hline \multicolumn{16}{|c|}{ Expt. 1} \\
\hline None & \multicolumn{2}{|c|}{$17.1 \mathrm{ab}^{\mathrm{z}}$} & \multicolumn{2}{|c|}{$0.84 \mathrm{ab}$} & \multicolumn{2}{|c|}{$7.8 \mathrm{~b}$} & & $3.1 \mathrm{a}$ & $3.1 \mathrm{ab}$ & $0.0^{\mathrm{NS}}$ & \multicolumn{2}{|c|}{$0.75 \mathrm{~b}$} & & \multicolumn{2}{|c|}{$1.114 \mathrm{~b}$} \\
\hline $10 \%$ biochar & \multicolumn{2}{|c|}{$16.8 \mathrm{ab}$} & \multicolumn{2}{|c|}{$0.79 \mathrm{ab}$} & \multicolumn{2}{|c|}{$8.6 \mathrm{ab}$} & & $2.7 \mathrm{~b}$ & $3.3 \mathrm{ab}$ & $-0.6^{*}$ & \multicolumn{2}{|c|}{$0.75 \mathrm{~b}$} & & \multicolumn{2}{|c|}{$1.170 \mathrm{~b}$} \\
\hline $20 \%$ biochar & \multicolumn{2}{|c|}{$15.6 \mathrm{~b}$} & \multicolumn{2}{|c|}{$0.66 \mathrm{~b}$} & \multicolumn{2}{|c|}{$8.3 \mathrm{~b}$} & & $2.8 \mathrm{~b}$ & $3.4 \mathrm{a}$ & $-0.6^{*}$ & \multicolumn{2}{|c|}{$0.74 \mathrm{~b}$} & & \multicolumn{2}{|c|}{$1.174 \mathrm{ab}$} \\
\hline $10 \%$ biochar-bokashi & \multicolumn{2}{|c|}{$18.1 \mathrm{a}$} & \multicolumn{2}{|c|}{$0.87 \mathrm{ab}$} & \multicolumn{2}{|c|}{$9.0 \mathrm{a}$} & & $3.5 \mathrm{a}$ & $3.3 \mathrm{ab}$ & $0.2^{\mathrm{NS}}$ & \multicolumn{2}{|c|}{$0.86 \mathrm{a}$} & & \multicolumn{2}{|c|}{$1.251 \mathrm{a}$} \\
\hline $20 \%$ biochar-bokashi & \multirow{2}{*}{\multicolumn{2}{|c|}{$18.8 \mathrm{a}$}} & 0.9 & & & $0 \mathrm{a}$ & & $3.6 \mathrm{a}$ & $2.7 \mathrm{~b}$ & $0.9 * *$ & & & & & $12 \mathrm{a}$ \\
\hline Avg & & & 0.73 & 0.91 & 8.2 & 8.9 & & & & & & & & 1.130 & 1.279 \\
\hline Significance & & & & & & & & & & & & & & & \\
\hline Amendment & & & & & & $* *$ & & & NS & & & & & & ** \\
\hline Inoculum & & & & & & $* *$ & & & NS & & & & & & ** \\
\hline $\begin{array}{l}\text { Amendment } \\
\times \text { inoculum }\end{array}$ & & & & & & NS & & & ** & & & & & & NS \\
\hline & & & & & & & Expt. & & & & & & & & \\
\hline None & & $\mathrm{b}$ & & & $5.8 \mathrm{a}$ & $7.9 \mathrm{bc}$ & $-2.1 * *$ & & 2.6 & & $1.23 \mathrm{a}$ & $0.93 \mathrm{a}$ & $0.30 * *$ & & $65 \mathrm{~b}$ \\
\hline $10 \%$ biochar & 11 & & & & $5.2 \mathrm{a}$ & $5.8 \mathrm{~d}$ & $-0.6^{*}$ & & 2.6 & & $1.12 \mathrm{a}$ & $0.93 \mathrm{a}$ & $0.19 *$ & & $64 \mathrm{a}$ \\
\hline $20 \%$ biochar & 10 & $\mathrm{ab}$ & & $3 \mathrm{~b}$ & $4.9 \mathrm{a}$ & $6.5 \mathrm{c}$ & $-1.6 * *$ & & 2.4 & & $1.17 \mathrm{a}$ & $0.93 \mathrm{a}$ & $0.25 * *$ & & $11 \mathrm{a}$ \\
\hline $10 \%$ biochar-bokashi & 11 & & & & $5.7 \mathrm{a}$ & $7.8 \mathrm{~b}$ & $-2.1 * *$ & & 2.5 & & $1.06 \mathrm{a}$ & $0.97 \mathrm{a}$ & $0.08^{\mathrm{NS}}$ & & $39 \mathrm{a}$ \\
\hline $20 \%$ biochar-bokashi & 11 & & & & $5.8 \mathrm{a}$ & $10.0 \mathrm{a}$ & $-4.2 * *$ & & 2.6 & & $1.07 \mathrm{a}$ & $1.09 \mathrm{a}$ & $-0.02^{\mathrm{NS}}$ & & $07 \mathrm{a}$ \\
\hline Average & 10.3 & 11.3 & 0.69 & 0.55 & 5.5 & 7.5 & & 2.9 & 2.2 & & 1.14 & 0.96 & & 1.33 & 1.27 \\
\hline Significance & & & & & & & & & & & & & & & \\
\hline Amendment & & & & & & $* *$ & & & NS & & & & & & $*$ \\
\hline Inoculum & & & & & & $* *$ & & & ** & & & & & & ** \\
\hline $\begin{array}{l}\text { Amendment } \\
\times \text { inoculum }\end{array}$ & & & & & & $* *$ & & & NS & & & & & & NS \\
\hline
\end{tabular}

${ }^{\mathrm{z}}$ Means followed by the same letter within a column in each experiment are not significantly different at $P \leq 0.05$ (Tukey's test).

$\mathrm{NI}=$ noninoculated; $\mathrm{I}=$ inoculated with $P$. cinnamomi.

NS, *,**Nonsignificant or significant at $P \leq 0.05$ or 0.01 , respectively. 
Table 5. Effects of a combination of soil amendments with biochar and inoculation with Phytophthora cinnamomi on the concentration of micronutrients in leaves of 'Legacy' blueberry in Expts. 1 and 2.

\begin{tabular}{|c|c|c|c|c|c|c|c|c|c|c|c|c|c|c|c|}
\hline \multirow[b]{2}{*}{ Soil amendment } & \multicolumn{3}{|c|}{$\mathrm{B}\left(\mu \mathrm{g} \cdot \mathrm{g}^{-1}\right)$} & \multicolumn{3}{|c|}{$\mathrm{Cu}\left(\mu \mathrm{g} \cdot \mathrm{g}^{-1}\right)$} & \multicolumn{3}{|c|}{$\mathrm{Fe}\left(\mu \mathrm{g} \cdot \mathrm{g}^{-1}\right)$} & \multicolumn{3}{|c|}{$\operatorname{Mn}\left(\mu g \cdot g^{-1}\right)$} & \multicolumn{3}{|c|}{$\mathrm{Zn}\left(\mu \mathrm{g} \cdot \mathrm{g}^{-1}\right)$} \\
\hline & $\mathrm{NI}$ & $\mathrm{I}$ & $\overline{\text { Difference }}$ & $\mathrm{NI}$ & I & $\overline{\text { Difference }}$ & $\mathrm{NI}$ & I & $\overline{\text { Difference }}$ & $\mathrm{NI}$ & I & $\overline{\text { Difference }}$ & $\mathrm{NI}$ & I & Difference \\
\hline \multicolumn{16}{|c|}{ Expt. 1} \\
\hline None & $62 \mathrm{a}^{\mathrm{z}}$ & $49 \mathrm{a}$ & $13 * *$ & $6.7 \mathrm{a}$ & $7.0 \mathrm{a}$ & $-0.3^{\mathrm{NS}}$ & \multicolumn{3}{|c|}{42} & $148 \mathrm{a}$ & $123 \mathrm{ab}$ & $25^{*}$ & $10.6 \mathrm{a}$ & $14.9 \mathrm{a}$ & $-4.3 * *$ \\
\hline $10 \%$ biochar & $52 \mathrm{ab}$ & $54 \mathrm{a}$ & $-2^{\mathrm{NS}}$ & $6.5 \mathrm{a}$ & $10.7 \mathrm{a}$ & $-4.2 * *$ & \multicolumn{3}{|c|}{44} & $119 \mathrm{ab}$ & $148 \mathrm{a}$ & $-29 *$ & $8.8 \mathrm{ab}$ & $15.6 \mathrm{a}$ & $-6.8 * *$ \\
\hline $20 \%$ biochar & $48 \mathrm{~b}$ & $55 \mathrm{a}$ & $-7^{\mathrm{NS}}$ & $5.1 \mathrm{a}$ & $10.6 \mathrm{a}$ & $-5.5 * *$ & \multicolumn{3}{|c|}{49} & $114 \mathrm{~b}$ & $126 \mathrm{ab}$ & $-12^{\mathrm{NS}}$ & $7.8 \mathrm{~b}$ & $12.4 \mathrm{a}$ & $-4.6 * *$ \\
\hline $10 \%$ biochar-bokashi & $50 \mathrm{~b}$ & $55 \mathrm{a}$ & $-5^{\mathrm{NS}}$ & $6.2 \mathrm{a}$ & $10.5 \mathrm{a}$ & $-4.3 * *$ & \multicolumn{3}{|c|}{45} & $128 \mathrm{ab}$ & $129 \mathrm{ab}$ & $-1^{\mathrm{NS}}$ & $11.0 \mathrm{a}$ & $13.1 \mathrm{a}$ & $-2.1^{\mathrm{NS}}$ \\
\hline $20 \%$ biochar-bokashi & $48 \mathrm{~b}$ & $56 \mathrm{a}$ & $-8 *$ & $6.2 \mathrm{a}$ & $10.7 \mathrm{a}$ & $-4.5 * *$ & \multicolumn{2}{|c|}{48} & & $129 \mathrm{ab}$ & $122 \mathrm{~b}$ & $7^{\mathrm{NS}}$ & $11.1 \mathrm{a}$ & $12.2 \mathrm{a}$ & $-1.1^{\mathrm{NS}}$ \\
\hline Avg & & & & 6.1 & 9.9 & & 42 & 49 & & & & & 9.9 & 13.6 & \\
\hline \multicolumn{16}{|l|}{ Significance } \\
\hline Amendment & \multicolumn{3}{|c|}{ NS } & \multicolumn{3}{|c|}{$*$} & \multicolumn{3}{|c|}{ NS } & \multicolumn{2}{|c|}{ * } & \multicolumn{4}{|c|}{$*$} \\
\hline Inoculum & \multicolumn{2}{|c|}{ NS } & & \multicolumn{2}{|c|}{$* *$} & & \multicolumn{3}{|c|}{$* *$} & \multicolumn{2}{|c|}{ NS } & \multicolumn{4}{|c|}{$* *$} \\
\hline $\begin{array}{l}\text { Amendment } \\
\times \text { inoculum }\end{array}$ & \multicolumn{2}{|c|}{$* *$} & & \multicolumn{3}{|c|}{$* *$} & \multicolumn{3}{|c|}{ NS } & \multicolumn{2}{|c|}{$* *$} & \multicolumn{4}{|c|}{$* *$} \\
\hline \multicolumn{16}{|c|}{ Expt. 2} \\
\hline None & 63 & & & & 0.4 & & $37 \mathrm{a}$ & $39 \mathrm{~b}$ & $-2^{\mathrm{NS}}$ & $166 \mathrm{a}$ & $103 \mathrm{a}$ & $63 * *$ & $10.9 \mathrm{a}$ & $13.4 \mathrm{a}$ & $-2.5 * *$ \\
\hline $10 \%$ biochar & 53 & & & & 9.6 & & $38 \mathrm{a}$ & $54 \mathrm{a}$ & $-16 * *$ & $164 \mathrm{a}$ & $101 \mathrm{a}$ & $63 * *$ & $11.5 \mathrm{a}$ & $11.9 \mathrm{a}$ & $-0.4^{\mathrm{NS}}$ \\
\hline $20 \%$ biochar & 51 & & & & 9.0 & & $34 \mathrm{a}$ & $39 \mathrm{~b}$ & $-5^{\mathrm{NS}}$ & $135 \mathrm{ab}$ & $103 \mathrm{a}$ & $32 *$ & $10.5 \mathrm{a}$ & $11.5 \mathrm{a}$ & $-1.0^{\mathrm{NS}}$ \\
\hline $10 \%$ biochar-bokashi & 59 & & & & 0.6 & & $44 \mathrm{a}$ & $32 \mathrm{~b}$ & $12 *$ & $127 \mathrm{~b}$ & $102 \mathrm{a}$ & $25^{\mathrm{NS}}$ & $11.7 \mathrm{a}$ & $10.4 \mathrm{a}$ & $1.3^{\mathrm{NS}}$ \\
\hline $20 \%$ biochar-bokashi & 63 & & & & 8.8 & & $45 \mathrm{a}$ & $43 \mathrm{~b}$ & $2^{\mathrm{NS}}$ & $140 \mathrm{ab}$ & $129 \mathrm{a}$ & $11^{\mathrm{NS}}$ & $11.7 \mathrm{a}$ & $12.0 \mathrm{a}$ & $0.3^{\mathrm{NS}}$ \\
\hline Avg & 61 & 56 & & 8.9 & 10.5 & & & & & 147 & 108 & & & & \\
\hline Significance & & & & & & & & & & & & & & & \\
\hline Amendment & $* *$ & & & & NS & & & * & & 1 & IS & & & & \\
\hline Inoculum & $* *$ & & & & $*$ & & & S & & & $*$ & & & & \\
\hline $\begin{array}{l}\text { Amendment } \\
\times \text { inoculum }\end{array}$ & $\mathrm{Ns}$ & & & & NS & & & $*$ & & & * & & & & \\
\hline
\end{tabular}

${ }^{\mathrm{z}}$ Means followed by the same letter within a column are not significantly different at $P \leq 0.05$ (Tukey's test).

$\mathrm{NI}=$ noninoculated; $\mathrm{I}=$ inoculated with $P$. cinnamomi.

Ns, *, **Nonsignificant or significant at $P \leq 0.05$ or 0.01 , respectively.

Table 6. Effect of soil amendments with biochar on root colonization by mycorrhizal fungi in 'Legacy' blueberry in Expts. 1 and $2 .^{z}$

\begin{tabular}{lcc}
\hline & \multicolumn{3}{c}{ Mycorrhizal colonization (\%) $^{\mathrm{y}}$} \\
\cline { 2 - 3 } Soil amendment & Expt. 1 & Expt. 2 \\
\hline None & $6 \mathrm{~d}^{\mathrm{x}}$ & $9 \mathrm{~d}$ \\
$10 \%$ biochar & $56 \mathrm{c}$ & $83 \mathrm{c}$ \\
$20 \%$ biochar & $79 \mathrm{~b}$ & $91 \mathrm{ab}$ \\
$10 \%$ biochar-bokashi & $80 \mathrm{ab}$ & $87 \mathrm{bc}$ \\
$20 \%$ biochar-bokashi & $85 \mathrm{a}$ & $94 \mathrm{a}$ \\
Significance & $* *$ & $* *$ \\
\hline
\end{tabular}

${ }^{\mathrm{z}}$ Noninoculated plants only. Mycorrhizal colonization was not examined in plants inoculated with Phytophthora cinnamomi.

${ }^{\mathrm{y}}$ Percentage of total root length with mycorrhizal structures (internal hyphae and hyphal coils).

${ }^{\mathrm{x}}$ Means followed by the same letter within a column are not significantly different at $P \leq 0.05$ (Tukey's test).

**Significant at $P \leq 0.01$.

Table 7. Effect of soil amendments with biochar on root infection by Phytophthora cinnamomi in 'Legacy' blueberry in Expts. 1 and $2 .^{\mathrm{z}}$

\begin{tabular}{|c|c|c|}
\hline \multirow[b]{2}{*}{ Soil amendment } & \multicolumn{2}{|c|}{ Root infection by P. cinnamomi $(\%)^{\mathrm{y}}$} \\
\hline & Expt. 1 & Expt. 2 \\
\hline None & 33 & 45 \\
\hline $10 \%$ biochar & 40 & 70 \\
\hline $20 \%$ biochar & 47 & 65 \\
\hline $10 \%$ biochar-bokashi & 37 & 60 \\
\hline $20 \%$ biochar-bokashi & 43 & 85 \\
\hline Significance & NS & NS \\
\hline
\end{tabular}

${ }^{\mathrm{z}}$ Only plants inoculated with $P$. cinnamomi are included in the analysis. Infection was not observed in roots of the noninoculated plants.

${ }^{\mathrm{y}}$ Percentage of ten 1-cm-long root pieces infected by $P$. cinnamomi.

NS $=$ nonsignificant.

aestivum L.) and radish (Raphanus sativus L.) in an acidic soil. In that case, soil $\mathrm{pH}$ was unaffected by biochar but declined with increasing rates of $\mathrm{N}$ application. Thus, if needed, acidifying fertilizers such as urea or ammonium sulfate could be used to moderate the liming effect of biochar on high-pH soils.
With the exception of $\mathrm{NO}_{3}-\mathrm{N}$ and $\mathrm{K}$ in one of the experiments (Expt. 2), biochar had no effect on soil nutrients. This was expected given that the woody materials from which the biochar was derived had low concentrations of many nutrients, including each macronutrient (Bollen, 1969). Consequently, biochar only altered the concentration of a few nutrients in the leaves of blueberry. As expected, adding bokashi to the biochar increased the concentration of several nutrients in the leaves, including $\mathrm{K}, \mathrm{Mg}$, and $\mathrm{S}$ under complete fertigation (Expt. 1) and N, P, and S under limited fertigation (Expt. 2). Compared with biochar, bokashi was relatively high in nutrients and, therefore, a good replacement for fertilizer.

With or without bokashi, biochar increased both shoot and root growth relative to blueberry plants grown in unamended soil. Increased root growth with biochar has been reported in a number of crops, including cowpea [Vigna minima (Roxb.) Ohwi \& H. Ohashi], wheat, and soybean [Glycine max (L.) Merr.] (Lehmann et al., 2003; ReyesCabrera et al., 2017; Solaiman et al., 2010). Blueberry has an extremely fine, fibrous root system and requires porous, well-drained soils for growth (Bryla et al., 2017). The physical structure of woody biochars increases pore space in soils and thereby could facilitate root penetration (Bruun et al., 2014). Based on visual observations in the present study, biochar appeared to increase aggregation of the sandy soil and, therefore, likely improved root penetration by blueberry. Absorption of nutrients by the biochar could also create nutrient patches, leading to more root growth, particularly when biochar is added with composted or fermented organic materials, such as bokashi (Hagemann et al., 2017).

Biochar and biochar-bokashi amendments also increased root colonization by ericoid mycorrhizal fungi by an average of 10 -fold in the blueberry plants. Others have 
reported similar increases in root colonization by arbuscular mycorrhizal and ectomycorrhizal fungi as a result of incorporating biochar into the soil before planting wheat (Solaiman et al., 2010) and larch [Larix gmelinii (Rupr.) Rupr.] seedlings (Makoto et al., 2010), respectively. Likewise, Duclos and Fortin (1983) reported increased root colonization of ericoid mycorrhizal fungi in lowbush blueberry (Vaccinium angustifolium Aiton) seedlings following the application of activated charcoal. In that case, the active carbon adsorbed toxic phenolic compounds in the rhizosphere. Excessive accumulations of such compounds in the rhizosphere might reduce the penetration of the hyphae into roots. In many ways, biochar is analogous to activated charcoal and, in fact, is known to absorb phenolic compounds that are potentially toxic to mycorrhizal fungi (Braghiroli et al., 2018; Hameed and Rahman, 2008). The highly porous nature of biochars also may provide a physical niche for mycorrhizal hyphae and offer physical protection against fungal grazers (Jaafar et al., 2014; Pietikäinen et al., 2000; Warnock et al., 2007). Enriched nutrient patches from the biochar also could increase development (Cui and Caldwell, 1996), and temporary sorption and release of signaling compounds could amplify overall signaling in the rhizosphere and promote colonization in the roots in soil with biochar (Warnock et al., 2007).

Plants inoculated with P. cinnamomi developed root rot, regardless of whether the soil was amended with biochar or biocharbokashi. Other studies have reported that soil pathogens, such as Phytophthora sp., were suppressed by low concentrations of biochar in the soil, but higher concentrations were ineffective or, in some cases, accelerated plant disease (Copley et al., 2015; Frenkel et al., 2017; Jaiswal et al., 2015; Zwart and Kim, 2012). Perhaps the rates of biochar used in the present study were too high to suppress development of $P$. cinnamomi in highbush blueberry. Biochars contain various types of organic compounds that are phytotoxic and suppress pathogens at lower dosages but could damage roots and increase susceptibility to disease at higher dosages (Bonanomi et al., 2015; Graber et al., 2014). Alternatively, the inoculation rate was high $\left(2.7 \mathrm{cfu}\right.$ per $\left.\mathrm{cm}^{3}\right)$ and may have overwhelmed the ability of biochar to provide any disease suppression.

Results of this study indicate that biochar could be a suitable soil amendment for commercial production of highbush blueberry. Benefits under controlled conditions included more plant growth in soil with biochar than in unamended soil and much greater levels of root colonization by mycorrhizal fungi. Biochar also appeared to improve soil aggregation but had relatively little effect on soil $\mathrm{pH}$ and plant nutrition and no effect on root infection by $P$. cinnamomi. Addition of bokashi to the biochar improved plant growth and nutrition, particularly under nutrientlimited conditions. Our next step is to test biochar in a new field planting of highbush blueberry and identify the best method and rate to apply it. Successful practices for using biochar will depend on plant response as well as the cost.

\section{Literature Cited}

Amendola, C., A. Montagnoli, M. Terzaghi, D. Trupiano, F. Oliva, S. Baronti, F. Miglietta, D. Chiatante, and G.S. Scippa. 2017. Short-term effects of biochar on grapevine fine root dynamics and arbuscular mycorrhizae production. Agric. Ecosyst. Environ. 239:236-245.

ASTM D422-63. 2007. Standard test method for particle-size analysis of soils. ASTM, West Conshohocken, PA.

Bird, M.I., P.L. Ascough, I.M. Young, C.V. Wood, and A.C. Scott. 2008. X-ray microtomographic imaging of charcoal. J. Archaeol. Sci. 35:2698-2706.

Boechat, C.L., J.A.G. Santos, and A.M.A. Accioly. 2013. Net mineralization nitrogen and soil chemical changes with application of organic wastes with 'fermented bokashi compost'. Acta Sci. Agron. 35:257-264.

Bollen, W.B. 1969. Properties of tree barks in relation to their agricultural utilization. USDA For. Serv. Res. Paper PNW 77.

Bollen, W. and D. Glennie. 1961. Sawdust, bark and other wood wastes for soil conditioning. For. Prod. J. 11:38-46.

Bonanomi, G., F. Ippolito, and F. Scala. 2015. A "black" future for plant pathology? Biochar as a new soil amendment for controlling plant diseases. J. Plant Pathol. 97:223-234.

Braghiroli, F.L., H. Bouafif, N. Hamza, C.M. Neculita, and A. Koubaa. 2018. Production, characterization, and potential of activated biochar as adsorbent for phenolic compounds from leachates in a lumber industry site. Environ. Sci. Pollut. Res. Int. 25:26562-26575.

Bruun, E.W., C.T. Petersen, E. Hansen, J.K. Holm, and H. Hauggaard-Nielsen. 2014. Biochar amendment to coarse sandy subsoil improves root growth and increases water retention. Soil Use Mgt. 30:109-118.

Bryla, D.R., R.G. Linderman, and W.Q. Yang. 2008. Incidence of Phytophthora and Pythium infection and the relation to cultural conditions in commercial blueberry fields. HortScience 43:260-263.

Bryla, D.R., L.R. Valenzuela-Estrada, and O.L. Vargas. 2017. Root production, distribution, and turnover in conventional and organic northern highbush blueberry systems. Acta Hort. 1180:169-176.

Christel, D.M. 2017. The use of bokashi as a soil fertility amendment in organic spinach cultivation. Univ. Vt., Burlington, MS Thesis.

Copley, T.R., K.A. Aliferis, and S. Jabaji. 2015. Maple bark biochar affects Rhizoctonia solani metabolism and increases damping-off severity. Phytopathology 105:1334-1346.

Cornelissen, G., Jubaedah, N.L. Nurida, S.E. Hale, V. Martinsen, L. Silvani, and J. Mulder. 2018. Fading positive effect of biochar on crop yield and soil acidity during five growth seasons in an Indonesian Ultisol. Sci. Total Environ. 634:561-568.

Costello, R.C., D.M. Sullivan, D.R. Bryla, B.C. Strik, and J.S. Owen. 2019. Compost feedstock and compost acidification affect growth and mineral nutrition in northern highbush blueberry. HortScience 54:1067-1076.

Cui, M. and M.M. Caldwell. 1996. Facilitation of plant phosphate acquisition by arbuscular mycorrhizas from enriched soil patches. 1. Roots and hyphae exploiting the same soil volume. New Phytol. 133:453-460.

Dahnke, W.C. and G.V. Johnson. 1990. Testing soils for available nitrogen, p. 127-140. In: R.L.
Westerman (ed.). Soil testing and plant analysis. 3rd ed. Soil Sci. Soc. Amer., Madison, WI.

Dias, B.O., C.A. Silva, F.S. Higashikawa, A. Roig, and M.A. Sánchez-Monedero. 2010. Use of biochar as bulking agent for the composting of poultry manure: Effect on organic matter degradation and humification. Bioresour. Technol. 101:1239-1246.

Duclos, J.L. and J.A. Fortin. 1983. Effect of glucose and active charcoal on in vitro synthesis of ericoid mycorrhiza with Vaccinium spp. New Phytol. 94:95-102.

Follovo, C., V. Cristofori, E. Mendoza de-Gyves, C.M. Rivera, R. Rea, S. Fanasca, C. Bignami, Y. Sassine, and Y. Rouphael. 2008. Leaf area estimation model for small fruits from linear measurements. HortScience 43:2263-2267.

Frenkel, O., A.K. Jaiswal, Y. Elad, B. Lew, C. Kammann, and E.R. Graber. 2017. The effect of biochar on plant diseases: What should we learn while designing biochar substrates? J. Environ. Eng. Landsc. Mgt. 25:105-113.

Gavlak, R., D. Horneck, and R.O. Miller. 2005. Soil, plant and water reference methods for the western region. 3rd ed. Western Region Extension Publication (WREP-125). WERA-103 Technical Committee. 30 Aug. 2019. <http://www.naptprogram. org/files/napt/western-statesmethod-manual2005.pdf>.

Giovannetti, M. and B. Mosse. 1980. An evaluation of techniques for measuring vesicular arbuscular mycorrhizal infection in roots. New Phytol. 84:489-500.

Graber, E.R., O. Frenkel, A.K. Jaiswal, and Y. Elad. 2014. How may biochar influence severity of diseases caused by soilborne pathogens? Carbon Mgt. 5:169-183.

Hagemann, N., S. Joseph, H.-P. Schmidt, C.I. Kammann, J. Harter, T. Borch, R.B. Young, K. Varga, S. Taherymoosavi, K.W. Elliott, A. McKenna, M. Albu, C. Mayrhofer, M. Obst, P. Conte, A. Dieguez-Alonso, S. Orsetti, E. Subdiaga, S. Behrens, and A. Kappler. 2017. Organic coating on biochar explains its nutrient retention and stimulation of soil fertility. Nat. Commun. 8:1089, doi: 10.1038/s41467-01701123-0.

Hameed, B.H. and A.A. Rahman. 2008. Removal of phenol from aqueous solutions by adsorption onto activated carbon prepared from biomass material. J. Hazard. Mater. 160:576-581.

Hart, J., B. Strik, L. White, and W. Yang. 2006. Nutrient management for blueberries in Oregon. Ore. St. Univ. Ext. Serv. Publ. EM8918.

Havlin, J.L., J.D. Beaton, S.L. Tisdale, and W.R. Nelson. 2005. Soil fertility and fertilizers: An introduction to nutrient management. 7th ed. Prentice Hall, Upper Saddle River, NJ.

Haynes, R. and R. Swift. 1986. Effect of soil amendments and sawdust mulching on growth, yield and leaf nutrient content of highbush blueberry plants. Scientia Hort. 29:229-238.

Horneck, D.A., D.M. Sullivan, J.S. Owen, and J.M. Hart. 2011. Soil Test Interpretation Guide Oregon State Extension EC 1478. 28 May 2019. <http://ir.library.oregonstate.edu/xmlui/ bitstreatm/handle/1957/22023/ec1478.pdf>.

Hossain, M.K., V. Strezov, and P.F. Nelson. 2015. Comparative assessment of the effect of wastewater sludge biochar on growth, yield and metal bioaccumulation of cherry tomato. Pedosphere 25:680-685.

International Biochar Initiative. 2015. Standardized product definition and product testing guidelines for biochar that is used in soil. 13 Dec. 2019. <https://www.biochar-international. org/wp-content/uploads/2018/04/IBI_Biochar_ Standards_V2.1_Final.pdf $>$. 
Jaafar, N.M., P.L. Clode, and L.K. Abbott. 2014. Microscopy observations of habitable space in biochar for colonization of fungal hyphae from soil. J. Integr. Agr. 13:483-490.

Jaiswal, A.K., O. Frenkel, Y. Elad, B. Lew, and E.R. Graber. 2015. Non-monotonic influence of biochar dose on bean seedling growth and susceptibility to Rhizoctonia solani: "the shifted $\mathrm{R}_{\max }$-effect." Plant Soil 395:125-140.

Jeffery, S., F.G.A. Verheijen, M. van der Velde, and A.C. Bastos. 2011. A quantitative review of the effects of biochar application to soils on crop productivity using meta-analysis. Agr. Ecosyst. Environ. 144:175-187.

Julian, J.W., B.C. Strik, and W. Yang. 2011. Blueberry economics: The costs of establishing and producing blueberries in the Willamette Valley. Ore. St. Univ. Ext. Serv. Publ. AEB 0022.

Kammann, C.I., H.-P. Schmidt, N. Messerschmidt, S. Linsel, D. Steffens, C. Müller, H.-W. Koyro, P. Conte, and S. Joseph. 2015. Plant growth improvement mediated by nitrate capture in cocomposted biochar. Scientific Rpt. 5:11080, doi: $10.1038 /$ srep11080.

Knowles, O.A., B.H. Robinson, A. Contangelo, and L. Clucas. 2011. Biochar for the mitigation of nitrate leaching from soil amended with biosolids. Sci. Total Environ. 409:3206-3210.

LeCroy, C., C.A. Masiello, J.A. Rudgers, W.C. Hockaday, and J.J. Silberg. 2013. Nitrogen, biochar, and mycorrhizae: Alteration of the symbiosis and oxidation of the char surface. Soil Biol. Biochem. 58:248-254.

Lehmann, J. and S. Joseph. 2009. Biochar for environmental management: An introduction, p. 1-12. In: J. Lehmann and S. Joseph (eds.). Biochar for environmental management: Science and technology. Earthscan, Sterling, VA.

Lehmann, J., J. Pereira da Silva, Jr., C. Steiner, T. Nehls, W. Zech, and B. Glaser. 2003. Nutrient availability and leaching in an archaeological Anthrosol and a Ferralsol of the Central Amazon basin: Fertilizer, manure and charcoal amendments. Plant Soil 249:343-357.

Lehmann, J., M.C. Rillig, J. Thies, C.A. Masiello, W.C. Hockaday, and D. Crowley. 2011. Biochar effects on soil biota - a review. Soil Biol. Biochem. 43:1812-1836.

Makoto, K., Y. Tamai, Y.S. Kim, and T. Koike. 2010. Buried charcoal layer and ectomycorrhizae cooperatively promote the growth of Larix gmelinii seedlings. Plant Soil 327:143-152.

McGonigle, T.P., M.H. Miller, D.G. Evans, G.L. Fairchild, and J.A. Swan. 1990. A new method which gives an objective measure of colonization of roots by vesicular-arbuscular mycorrhizal fungi. New Phytol. 115:495-501.

McLean, E.O. 1982. Soil pH and lime requirement, p. 199-224. In: A.L. Page, R.H. Miller, and D.R. Keeney (eds.). Methods of soil analysis. Part 2. Chemical and microbiological properties. 2nd ed. Amer. Soc. Agron., Soil Sci. Soc. Amer., Madison, WI.

Mehlich, A. 1984. Mehlich 3 soil test extractant: A modification of Mehlich-2 extractant. Commun. Soil Sci. Plant Anal. 15:1409-1416.

Meng, J., M. Tao, L. Wang, X. Liu, and J. Xu. 2018. Changes in heavy metal bioavailability and speciation from a $\mathrm{Pb}-\mathrm{Zn}$ mining soil amended with biochars from co-pyrolysis of rice straw and swine manure. Sci. Total Environ. 633:300-307.

Molnár, M., E. Vaszita, E. Farkas, E. Ujaczki, I. Fekete-Kertész, M. Tolner, O. Klebercz, C. Kirchkeszner, K. Gruiz, N. Uzinger, and V. Feigl. 2016. Acidic sandy soil improvement with biochar - a microcosm study. Sci. Total Environ. 563:855-865.

Nemati, M.R., F. Simard, J.-P. Fortin, and J. Beaudoin. 2015. Potential use of biochar in growing media. Vadose Zone J. 14, doi: 10.2136/vzj2014.06.0074.

Pierce, S., F. Quaglino, M. Montagna, A. Spada, P. Casati, and M. Iriti. 2016. Evaluation of Effective Microorganisms ${ }^{\circledR}$ efficacy on 'Candidatus Phytoplasma solani'-infected and healthy periwinkle plants. Mitteilungen Klosterneuburg 66:89-92.

Pietikäinen, J., O. Kiikkilä, and H. Fritze. 2000. Charcoal as a habitat for microbes and its effect on the microbial community of the underlying humus. Oikos 89:231-242.

Prost, K., N. Borchard, J. Siemens, T. Kautz, J.-M. Séquaris, A. Möller, and W. Amelung. 2013. Biochar affected by composting with farmyard manure. J. Environ. Qual. 42:164-172.

Retamales, J.B. and J.F. Hancock. 2018. Blueberries. 2nd ed. CABI, Cambridge, MA.

Reyes-Cabrera, J., R.G. Leon, J.E. Erickson, M.L. Silveira, D.L. Rowland, and K.T. Morgan. 2017. Biochar changes shoot growth and roo distribution of soybean during early vegetative stages. Crop Sci. 57:454-461.

Rezende, A.M.F.A., C.K. Tomita, and C.H. Uesugi. 2008. Cupric fungicides, benzalconium chlorides and liquid bioactive compost (Bokashi): Phytotoxicity and control of guava bacterial blight caused by Erwinia psidii. Trop. Plant Pathol. 33:288-294.

Robertson, G.P. and P.M. Groffman. 2015. Nitrogen transformations, p. 421-446. In: E.A. Paul (ed.). Soil microbiology, ecology, and biochemistry. 4th ed. Academic Press, San Diego, CA.

Sánchez-García, M., M. Sánchez-Monedero, A. Roig, I. López-Cano, B. Moreno, E. Benitez, and M. Cayuela. 2016. Compost vs biochar amendment: A two-year field study evaluating soil $\mathrm{C}$ build-up and $\mathrm{N}$ dynamics in an organically managed olive crop. Plant Soil 408:1-14.

Schulz, H. and B. Glaser. 2012. Effects of biochar compared to organic and inorganic fertilizers on soil quality and plant growth in a greenhouse experiment. J. Plant Nutr. Soil Sci. 175:410 422

Shin, K., G. van Diepen, W. Blok, and A.H.C. van Bruggen. 2017. Variability of Effective Microorganisms (EM) in bokashi and soil and effects on soil-borne plant pathogens. Crop Prot. 99:168-176.

Shulte, E.E. and B.G. Hopkins. 1996. Estimation of soil organic matter by weight loss-on-ignition, p. 21-31. In: F.R. Magdoff, M.A. Tabatabai, and E.A. Hanlon, Jr. (eds.). Soil organic matter: Analysis and interpretation. Soil Sci. Soc. Amer., Madison, WI.

Singh, B., B.P. Singh, and A.L. Cowie. 2010. Characterisation and evaluation of biochars for their application as a soil amendment. Aust. J. Soil Res. 48:516-525.

Sohi, S.P., E. Krull, E. Lopez-Capel, and R. Bol. 2010. A review of biochar and its use and function in soil. Adv. Agron. 105:47-82.

Solaiman, Z.M., P. Blackwell, L.K. Abbott, and P. Storer. 2010. Direct and residual effect of biochar application on mycorrhizal root colonisation, growth and nutrition of wheat. Aust. J. Soil Res. 48:546-554.

Strik, B.C., A.J. Vance, and C.E. Finn. 2017. Northern highbush blueberry cultivars differed in yield and fruit quality in two organic production systems from planting to maturity. HortScience 52:844-851.
Sullivan, D.M., D.R. Bryla, and R.C. Costello. 2014. Chemical characteristics of custom compost for highbush blueberry, p. 293-311. In: Z. $\mathrm{He}$ and H. Zhang (eds.). Applied manure and nutrient chemistry for sustainable agriculture and environment. Springer-Verlag, New York.

Suthar, R.G., C. Wang, M.C.N. Nunes, J. Chen, S.A Sargent, R.A. Bucklin, and B. Gao. 2018. Bamboo biochar pyrolyzed at low temperature improves tomato plant growth and fruit quality. Agriculture 8:153, doi: 10.3390/agriculture8100153.

Tsao, P.H. and S.O. Guy. 1977. Inhibition of Mortierella and Pythium in a Phytophthora isolation medium containing hymexazol. Phytopathology 67:796-801.

van Zwieten, L., S. Kimber, S. Morris, K.Y. Chan, A. Downie, J. Rust, S. Joseph, and A. Cowie. 2010. Effects of biochar from slow pyrolysis of papermill waste on agronomic performance and soil fertility. Plant Soil 327:235-246.

Vargas, O.L., D.R. Bryla, J.E. Weiland, B.C. Strik, and L. Sun. 2015. Irrigation and fertigation with drip and alternative micro irrigation systems in northern highbush blueberry. HortScience 50:897-903.

Wang, B., J. Lehmann, K. Hanley, R. Hestrin, and A. Enders. 2015. Adsorption and desorption of ammonium by maple wood biochar as a function of oxidation and $\mathrm{pH}$. Chemosphere 138:120-126.

Warnock, D.D., J. Lehmann, T.W. Kuyper, and M.C. Rillig. 2007. Mycorrhizal responses to biochar in soil - concepts and mechanisms. Plant Soil 300:9-20.

Weiland, J.E., A.H. Nelson, and G.W. Hudler. 2010. Aggressiveness of Phytophthora cactorum, $P$. citricola I, and $P$. plurivora from European beech. Plant Dis. 94:1009-1014.

Weiland, J.E., C.F. Scagel, N.J. Grünwald, E.A. Davis, B.R. Beck, and V.J. Fieland. 2018. Variation in disease severity caused by $P h y$ tophthora cinnamomi, $P$. plurivora, and Pythium cryptoirregulare on two rhododendron cultivars. Plant Dis. 102:2560-2570.

$\mathrm{Xu}$, H. 2000. Effects of a microbial inoculant and organic fertilizers on the growth, photosynthesis and yield of sweet corn. J. Crop Prod. 3:183-214.

$\mathrm{Xu}, \mathrm{T}$., L. Lou, L. Luo, R. Cao, D. Duan, and Y. Chen. 2012. Effect of bamboo biochar on pentachlorophenol leachability and bioavailability in agricultural soil. Sci. Total Environ. 414:727-731.

Yeo, J.R., J.E. Weiland, D.M. Sullivan, and D.R. Bryla. 2016. Susceptibility of highbush blueberry cultivars to phytophthora root rot. HortScience 51:74-78.

Yuan, J.-H. and R.-K. Xu. 2011. The amelioration effects of low temperature biochar generated from nine crop residues on an acidic Ultisol. Soil Use Mgt. 27:110-115.

Zhao, L., X. Cao, W. Zheng, Q. Wang, and F. Yang. 2015. Endogenous minerals have influences on surface electrochemistry and ion exchange properties of biochar. Chemosphere 136:133-139.

Zheng, R., Z. Chen, C. Cai, B. Tie, X. Liu, B. Reid, Q. Huang, M. Lei, G. Sun, and E. Baltrenaite. 2015. Mitigating heavy metal accumulation into rice (Oryza sativa L.) using biochar amendment - a field experiment in Hunan, China. Environ. Sci. Pollut. Res. Int. 22:1109711108.

Zwart, D.C. and S.-H. Kim. 2012. Biochar amendment increases resistance to stem lesions caused by Phytophthora spp. in tree seedlings. HortScience 47:1736-1740. 